\title{
Quelques lignes Claude Simon
}

Kostas Axelos

\section{(2) OpenEdition}

\section{Journals}

Édition électronique

URL : http://journals.openedition.org/ccs/461

DOI : $10.4000 /$ ccs.461

ISSN : 2558-782X

\section{Éditeur :}

Presses universitaires de Rennes, Association des lecteurs de Claude Simon

\section{Édition imprimée}

Date de publication : 31 décembre 2006

Pagination : 15

ISBN : 9782914518895

ISSN : 1774-9425

\section{Référence électronique}

Kostas Axelos, «Quelques lignes Claude Simon », Cahiers Claude Simon [En ligne], 2 | 2006, mis en ligne le 20 septembre 2017, consulté le 15 septembre 2020. URL : http://journals.openedition.org/ccs/ 461

Cahiers Claude Simon 


\section{Quelques lignes Claude Simon par Kostas AXELOS}

En parlant d'un autre, en l'occurrence de Claude Simon, en parlant avec un autre, le même, l'un et l'autre toujours présentsabsents, cela s'appelle un dialogue, ce qui " appartient " à l'un et ce qui " appartient " à l'autre se mêlent inextricablement. Parler de Claude Simon, ou avec lui, était et reste très difficile. Les lignes dites de la vie et celles de l'œuvre se nouent et se dénouent dans un réseau de renvois. Il n'y a pas un plan irrécusable sur lequel ce qui se rencontre et qui se raconte pourrait s'installer. Les lignes ne sont pas seulement fuyantes, comme on dit habituellement, elles ne parviennent jamais à surmonter ce qui les destine à demeurer énigmatiques, cela même qui n'est pas plus qu'il n'existe, mais se déploie unitairement, contradictoirement, multiplement. Et le trajet de la composition que compose l'écrivain et qui le compose, demeure marqué par un rythme à la fois continu et discontinu. Claude Simon ne fait pas ce qui depuis quelques siècles est désigné par le nom de littérature ; il est requis par l'écriture. Cette écriture et son monde n'obéissent pas à la loi de ce qui est défini comme poésie; ils reçoivent et ils lancent l'appel de la poéticité, cet innommable nom de l'ouverture. 